\title{
Articles
}

\section{Environment as Justice: Interpreting the State(s) of Drowning and Undercurrents of Power in Ghana}

\author{
Kirsty Wissing \\ School of Culture, History and Language \\ Australian National University, Canberra \\ kirsty.wissing@anu.edu.au
}

\begin{abstract}
This article explores Akwamu understandings of the Volta and other rivers in Ghana - valued for their life-giving qualities - when they become the opposite: the cause of death by drowning. By engaging with customary ideas of the environment as an active player, influenced by deities, I seek to map local Akwamu perspectives of the environment as justice onto international models that posit the environment in need of justice and guardianship through human management. Akwamu traditional authorities have described river environments as a fair and unbiased avenue through which to resolve disputes. By dwelling on drowning, I explore Akwamu and broader Akan notions of 'good' or 'natural' compared to 'bad' or 'unnatural' deaths, the latter thought to reflect human-environment and inter-human social breakdown as well as the moral worth of the drowned victim. Through customary ritual practices, traditional representatives separate the Akwamu state, or society, from an individual's bad, watery death and restore humanenvironment and inter-human order in social life on land. Stir the waters, however, and Akwamu understandings of rivers highlight a hierarchy in human-environment relations as well as undercurrents of power between humans. By analysing beliefs, interpretations, and ritual behaviours in response to drowning, I reconceptualise Akwamu dynamics of power in reflections on environments as justice.
\end{abstract}

\section{Introduction}

One day in July 2017, I witnessed the opening of a new court building at a town called Senchi (Senkyi) in the Akwamu traditional area of southern Ghana. Judges from both national and district levels, police and immigration officials, politicians and the district chief executive all assembled as 
representative authorities of judicial law on behalf of Ghanaian society. Seated directly opposite them were the Akwamu paramount chief and queen mother, their respective spokespersons and other senior traditional authorities for the Akwamu state of people on whose traditional land the court was established. Here were two courts of justice, each with representatives asserting authority to judge over individuals and sectors of Ghanaian society, positioned facing each other in a performance of mutual accountability and legal pluralism (Apoh, Wissing, Treasure and Fardin, 2017, p. 372; Mumma, 2005, p. 24; Ubink, 2008, pp. 20-21). However, such human courts are not the only avenues though which to seek justice.

For many Akwamu people in southern Ghana, concepts of social cohesion and justice are also embedded in their relationship to environments, including waterscapes. While rivers such as the Volta River have provided drinking water, cleanliness, trade, farming, fish, and other physical contributions, they also serve another important role: as a reflection and adjudication of disputes. The act of swearing, and cursing, on the Volta and other rivers is thought to glean evidence for or against people's claims in a dispute. For, as Nana Samanhyia Darko II - an advisor to the Akwamu traditional court - told me, "you can't lie and swear to the river" (personal communication, May 5, 2016).

With deities thought to control each fresh water river, human drowning and other water-related mishaps can signify more than mere misfortune. Rather, they are interpreted as reflecting non-human spiritual judgement of human morality. These interpretations highlight a hierarchy in humanenvironment relations as well as undercurrents of power between humans. Other religious understandings - particularly those of various Christian denominations and, to a lesser extent, Islam - are also present and sometimes co-exist with the worldviews of many Akwamu people in relation to environment. However, fundamental values of the Akwamu state regarding water and associated deities remain influential. Due to limited space, this article does not address Christian and other understandings, but rather focuses on pre-Christian Akwamu beliefs that persist today. In dwelling on death in water, this article contemplates justice and state(s) of power as explored through Akwamu interpretations of river drownings.

After briefly reviewing some international models of environment in need of justice, this article unpacks Akwamu understandings of their water environment as not only life-giving, but also life-taking, and asks how death by drowning can be seen as justice. To do this, I explore Akwamu and broader Akan notions of 'good' or 'natural' compared to 'bad' or 'unnatural' deaths, the latter thought to reflect human-environment and inter-human 
social breakdown as well as the moral worth of the deceased victim. I analyse customary ritual practices that physically shift the drowning victim from watery ambiguity to certainty and finality on land. These rituals are also believed to symbolically shift the broader Akwamu state and society from uncertainty associated with an individual's bad death, back to an everyday social life that reinforces social order and hierarchy. By analysing beliefs, interpretations, and ritual behaviours in response to drowning, I reconceptualise Akwamu dynamics of power in reflections on river environments as justice.

\section{Water environments: Victim, partner or overseer of humans?}

As a critical marker of environment, water has received much academic attention. This ranges from analysis of Indigenous water world-views (Austin-Broos, 2009; McWilliam, Palmer \& Shepherd, 2014; Strang, 2005a; Strang, 2005b; Watts, 2008) to the political manipulation of water to manipulate people for (nation-) state purposes (Bichsel, 2016; Wittfogel, 1957) that emphasise links, rather than divisions, between nature and culture(s). Water has also captured the academic imagination at both the African continental (Drewal, 2008; Fontein, 2015; Peters, 1994) and Ghanaian level (Akyeampong, 2001; Amuquandoh, 2010; Cless, 2012, pp. 102-105; Greene, 2002; McCaskie, 2009; Opoku \& Wicker, 2008; Rattray, 1927).

Emmanuel Akyeampong notes that "insights from ecological anthropology highlight the fact that, for African societies, the dichotomy or opposition between culture and nature is often inapplicable ... the cooperation between humans and nature is necessary to the production of culture and nature" (2001, p. 13, emphasis added). This article will focus on the nature of water, as an essential and intrinsically social resource, to analyse how it both "appears as a mirror" (Cless \& Hahn, 2012, p. 16) but also coproduces human-environment relations in what Akyeampong refers to as an "'eco-social' history" (2001, pp. 2, 4) as well as inter-human relations. Krause and Strang term this connectivity "hydro-sociality" (2016; see also Anand, 2011; Linton \& Budds, 2014). Such co-production of nature and culture is not always equal, but can be hierarchical. How that hierarchy looks, however, differs across global and local understandings of the environment.

Natural water and other environments are often depicted as being at the mercy of exploitation yet simultaneously in need of protection by humans. Discussions such as the "anthropocene" often begin from such a framework, emphasising the "major and still growing impacts of human activities on the earth and atmosphere ... [that caused] the current geological epoch ... [and] 
will continue over long periods" (Crutzen and Stoermer, 2000, p. 17). Anthropocene scholarship focuses on world-wide connected, human-induced problems that leave limited space for non-human actors as may be understood at the local community level. This approach risks overlooking the ways that local beliefs and practices articulate with, or counter, national and global dynamics and offer alternate understandings of responsibility and justice that attribute the environment - or religious entities deemed responsible for the environment - an active and influential role.

An alternate model gaining global attention is legal recognition of the environment enmeshed into human society as part, rather than apart, of Indigenous kinship structures. For example, in New Zealand, the Whanganui River was granted the same legal rights as humans in March 2017 (TalbotJones, 2017). Gerrard Albert, a Maori Whanganui iwi (people, or tribe) member and lead negotiator in the case, explained that "the reason we have taken this approach is because we consider the river an ancestor and always have" (Roy, 2017). In The Guardian (March 16, 2017), Roy remarked: "the new status of the river means ... the law now sees no differentiation between harming the tribe or harming the river because they are one and the same." Maru-Lanning similarly echoes the inter-relatedness of Indigenous peoples and rivers in New Zealand: "Waikato River lies at the heart of Waikato Maori tribal identity and chiefly power" (2010, p. 17). For the Whanganui River, two human guardians have been appointed to act on its behalf, one from the crown and one from the Whanganui iwi.

These models understand the environment as either vulnerable victim or equal citizen yet still in need of human guardianship. Both models position humans as necessary protectors of environments, and neither affords the environment a completely superior role to humans. In contrast, Akyeampong (2001, p. 1), writing of the Anlo people in southern Ghana, describes a circumstance of "unequal battle between humans and nature" where the latter dominates the former. By embracing traditional ecological knowledge theory (Menzies, 2006) and engaging with customary ideas of environment as an active player, this article seeks to map local Akwamu understandings in Ghana of environment as justice onto more global "flows" (Rockefeller, 2011) and situate them among debates that posit the environment as needing justice through human management.

\section{Methodology}

This article draws on information collected during fourteen months of research conducted in southern Ghana in 2016, 2017 and 2019. Data collection methods included participant observation, individual and group 
interviews, and archival and literature reviews. All information marked as personal communication in this article refers to interviews. Research participants who informed this article included Akwamu representatives such as chiefs, queen mothers, "linguists", ${ }^{1}$ shrine priests, community opinion leaders and other local residents. Although many people quoted in this article hold traditional titles, they often live among and undertake similar livelihood activities to other Akwamu community residents. Titled research participants engage in farming, trading, the textile industry and local radio broadcasting among other economic activities. This article primarily considers Akwamu attitudes to the Volta and other rivers; however, I also conducted research with non-Akwamu actors. These included representatives of the Volta River Authority, the Water Resources Commission, the Water Research Institute, the Environmental Protection Authority and the Volta River Basin Project based at the University of Ghana. I conducted research in communities surrounding the Volta River including Akwamufie, Akosombo, Atimpoku, Adjena Pesse, Dwenease, Abidjan Mami Wata Village, as well as in Ghana's capital city, Accra. During research, the author lived in Akwamufie and Akosombo, and most, but not all, of the ethnographic material is from these communities.

\section{Water and people in southern Ghana}

In this article, I focus on the Akwamu, who are a Twi-speaking people located in the Eastern Region in the southern part of Ghana. This group share similar cultural and linguistic traits with other groups such as Ahanta, Akim (Akyem), Akwapim (Akuapem), Ashanti (Asante), Brong, Fante (Fanti), Denkyira, Kwahu (Kwawu), Nzema, Sefwi, and Wassa, who at times identify under a larger group identity as Akan (Adinkrah, 2016, p. 140). Originally a large, militarily organised people with vast territories in what are now modern-day Ghana, Togo, and Benin (Agyekum, 2015; Akyeampong, 2001, p. 7; Wilks, 2001), the Akwamu now claim ownership over a much smaller territory that straddles the Volta River and Lake, and includes the Akosombo Dam.

In similarity with other societies in southern Ghana (cf. Beecham 1968 [1841], pp. 174-175; McCaskie 1995, p. 109), Akwamu people understand spiritual forces/beings to be unalienably associated with natural features.

\footnotetext{
1 For Akan cultural groups, a linguist is a traditional spokesperson who acts as an intermediary between chiefs and queen mothers and people that come to speak to them. In doing this, linguists endorse as well as share the responsibility of the content of words of chiefs and queen mothers.
} 
Thomas McCaskie writes "Asante culture and society were quite literally hacked out of nature" (1989, p. 521). While this was in relation to them utilising and mastering unruly nature on land, there are also strong links between society and water environments in much of southern Ghana (cf. Akyeampong, 2001; and Greene, 2002 for the Anlo people; and McCaskie, 1995, pp. 109, 117-118; and Rattray, 1923, 1927 for the Asante).

Akyeampong remarks of the Anlo ethnic group residing near the Volta's estuary: "on the Anlo coast humans were involved in a dynamic relationship with their environment, changing and being changed by it" (2001, p. 2). Further upstream, the Akwamu also adjust, and are adjusted by, the Volta River, known locally as Asuo Firaw, which is said to be a god (Asuogyasan Yaw Boadu IV, Akwamu chief of the rear guard, personal communication, November 10, 2017).

In thinking about water, Akwamu and broader Akan perspectives counter ideas of a hydro-social hierarchy where nature is vulnerable victim. Rather, nature, as controlled by deities, holds an ever-present potential to overrule humans/culture and when sociality breaks down to punish accordingly. A worldview of environment as, rather than in need of, justice does not necessarily flatten out or discard human hierarchy. Instead, I propose that Akwamu interpretations of the impacts of nature, specifically drowning in water, actually reinforce human social order and benefit some humans over others.

As the Asante viewed the River Tano as spiritually potent and able to heal a person from acts of bitterness by their enemy (McCaskie, 1995, p. 118), so too the Akwamu understand the spirits that control the waterscapes to be friendly and protectors. For instance, Odeneho Kwafo Akoto III, Akwamu paramount chief, explained that Odaasekyi, the god of cataracts, prevents and protects people from capsizing their canoes on the Volta River during a storm (personal communication, June 27, 2016). This has implications for how the Akwamu interpret drownings and attribute responsibility or blame.

Hans Peter Hahn reflects that "water is relevant not only as something useful, but also as a threat to people" (2012, p. 24). Veronica Strang has remarked, "in creating 'life', water creates form and order, and death, with its de-forming dis-incorporation, is the ultimate dis-order" (2004, p. 65). Therefore, what happens when water as the source of life inverts to become the cause of physical death? Can persons and social stability as related through the prism of water as life be achieved, maintained, or retracted in the context of death by drowning? 


\section{Dwelling on death in water}

In Ghana, as in many other places, death is generally undesirable (cf. Nketia, 1955, p. 6, and Sarpong, 1974, p. 22, as discussed in Sjaak van der Geest 1980, p. 166). This is even more so for death by drowning which is viewed as shocking and premature. Premature deaths in general are "regarded as much less natural" (van der Geest, 1980, p. 168) and need both explanation and classification. For various Akan groups, deaths can be classified as "good" and "bad" (cf. Adinkrah, 2016, p. 143; McCaskie, 1989, p. 429; van der Geest, 2004, p. 904), or sometimes as "natural" and "unnatural" (Adinkrah, 2016; see also van der Geest, 1980, pp. 167-168). Within the classification of bad or unnatural deaths, there seems further division into two categories: "the first consists of accidental deaths. The second comprises self-inflicted deaths or those deaths where the decedent deliberately caused his own death" or spiritual wrath (Adinkrah, 2016, p. 150). The Akwamu classify drowning as bad, and then further categorise the drowning as an accident or spiritual curse. I suggest these classifications highlight and reinforce existing power relations.

From discussions with some Akwamu chiefs, a shrine priest, and community opinion leaders, it seems an accidental, albeit bad death by drowning is said to have taken place if the corpse is bloated with water. Moreover, it is believed that the body will come out of the river of its own accord (without ritual ceremony) and in the same place that the drowning occurred. In contrast, if a drowning is thought to be spiritually invoked, the victim will not resist the drowning and their corpse will not contain water. As Nana Samanhyia Darko II remarked, "those who they have cast spell they don't drink water. Most of them don't even struggle" (personal communication, May 11, 2016). He continued to explain that if an accident such as a boat capsizing happens then those who know how to swim could rescue people. However, if a spell is cast on a person and they fall into the river, they will die.

Bad, or unnatural, deaths are known in the Akan Twi language as "otวfo" (Nana Afrakoma II, paramount queen mother, personal communication, September 15, 2017; Nana Appiah-Nti III, chief of Appiahkrom, personal communication, June 18, 2016 and April 12, 2019, using the Akwamu/Akwapim Twi spelling²), "otofos" (Adinkrah, 2016, p. 150, using the Asante Twi spelling) or "atofo," (McLeod, 1981, pp. 37-38). Mensah Adinkrah notes that

\footnotetext{
${ }^{2}$ Because this article relates to the Akwamu Traditional Area, Akwamu/Akwapim Twi spelling will be used unless another author's work is directly quoted.
} 
Among the Akan if a person dies through an accident, the death is not considered natural .... Such deaths are called atofowuo and the decedent is described as otofos. Unnatural deaths (otofowuo) signifies a cursed death, a bad death, or a dishonourable death and the decedent (otofos) is said to have been cursed" (2016, p. 150).

Other terms might also apply such as B. R. Stucki's use of the term anwobabu (1995, p. 141, cited in van der Geest, 2004, p. 904).

J. H. Nketia notes that the Akan juxtapose accidental death, death by suicide, death through childbirth or "death suspected to be caused by witchcraft, sorcery, or poison" (1969 [1955], p. 5) - which might be classified as t $\supset$ fo - as distinct from death after a known illness or from old age. Old age is "considered natural because it is presumed that the decedent died his or her destined ${ }^{3}$ death (wawu ne krawuo)" (Adinkrah, 2016, p. 145). van der Geest (2004, p. 904) unpacks the work of Miescher (1997, p. 529), Sarpong (1974, p. 35), Baaré (1986, pp. 55-56) and Bartle (1977, pp. 393) to also discuss distinctions between, and examples of, a good and bad death. Cases classified as stofo deaths include drowning, a vehicle accident, death by fallen tree, lightning strike, or snake bite, war or military combat, or maternal mortality during pregnancy or childbirth, or thunderstruck (lightening) (Adinkrah, 2016, p. 150). These deaths are not only considered bad, but also inauspicious (McLeod, 1981, p. 37).

Drowning and other tragic, untimely deaths "were believed to be punishments for sins" (van der Geest, 2004, p. 5) and moral transgressions. Accordingly, they were and are socially stigmatised. For, as McLeod writes, "the defining characteristic of all these people ... [is] that they were, in some sense, damaged or incomplete beings" (1981, p. 37). The Akwamu people see the Volta River, and the Akwamu deity Mfwodwo thought to control this river, as transparent and able to judge fairly rather than maliciously. With this assumed transparency, then, river drownings are interpreted as punishment for something morally wrong with the drowning victim. Nana Samanhyia Darko II remarked that even if you fall into the river and do not know how to swim, "we will save you, but if there is something wrong with you no matter what, we cannot save you" (personal communication, May 11, 2016).

In Akwamu understandings, humans are seen as inferior to deities that control the water environment, and human arrogance toward the environment is considered punishable. For example, Nana Tete Amo, the Akwamu shrine

\footnotetext{
${ }^{3}$ See Fortes (1959) for the role that destiny might play in "bad deaths," or misfortunes, as a deviation from a "good destiny" or as the result of a bad spirit (Greene 2002, pp. 87-88).
} 
priest responsible for the deity Mfwodwo, advised that he is not allowed to cross the Volta River, which is viewed as more powerful than even this senior religious authority (personal communication, June 22, 2016). Should he challenge this hierarchy and breach the taboo, it is feared that Mfwodwo will inflict spiritual punishment and trouble will follow.

Other social breakdowns include disrespect of, or lack of adherence to taboos, such as fishing and swimming in the Volta River during the sacred day of Akwasidae and before the annual yam offering festival. These times are considered very dangerous for an individual to visit the water, but some people still proceed. Nana Tete Amo said that breaching this taboo will incur a fine of one pure white ram, two bottles of schnapps and some money (personal communication, June 22, 2016). Neglect of ceremonial obligations is also said to upset the gods and leave Akwamu people vulnerable to death through drowning.

Adinkrah writes that Akan see unnatural deaths as "symptomatic of some taboo violation by the decedent and ... punishment for such an infraction" (2016, pp. 150-151). Nana Tete Amo said that if it is the Volta River that "picks" or subsumes a person as a form of punishment, this person will not be seen again until a shrine priest performs the necessary rituals after which the river will release the victim's body again, and return it to the bank (personal community, June 22, 2016).

The Volta River is also thought to reflect judgement about inter-human social discord. Nana Samanhyia Darko II advised that if a person wanted to avoid chiefs or court processes but sought to uncover the truth of a matter, then such a person would take someone they suspect of doing them wrong such as a friend cheating on them with their wife - to the river (personal communication, May 11, 2016). He continued that if the person is guilty, it will not even take three days for the offender to walk into the river and die. This death is interpreted as the river meting out justice for (socially defined) human wrongdoing seen to cause disharmony.

In addition, river drownings can shed light on inter-ethnic human sociality in the case of Akwamu-'stranger' (non-Akwamu) relations. Nana Samanhyia Darko II stated that "it will be rare to hear of an Akwamu die in the river. Why? Because we respect and revere the river." This was in contrast, he said, with "the squatters," often fishing communities from a different but neighbouring Ewe language group, that he claimed disrespect and defecate into the river and also drown (but see Opoku and Wicker (2008) for the migratory history and water beliefs of certain Ewe people residing in the Akwamu traditional area of this research study). 
This does not mean that Akwamu people cannot also breach taboos or drown. Rather, it highlights some inter-ethnic contestation over control and appropriate uses in/of the Volta River. These have, in the past, come to a head between Akwamu traditional authorities and non-Akwamu (mainly Ewe) night fishermen that, the former claim, breach Akwamu customary taboos by fishing during sacred days. Interpretations such as that of Nana Samanhyia Darko II about non-Akwamu drownings as spiritual punishment by an (Akwamu) deity could be read as a claim for superior Akwamu understandings of and relations to this particular water environment.

\section{(Social) life after death? Restoring hydro-social balance}

For the central African region, J. Matthew Schoffeleers has written that "serious abuses in a community lead to ecological disaster, which in turn threatens the life of the community" $(1979$, p. 5). In the Akwamu context in Ghana, an individual's serious social breach is believed to manifest in environmental upheaval that not only brings punishment via drowning to the individual, but also threatens society more generally. To restore the balance and the hierarchy of Akwamu human-environment relations with their deities, pacification rituals are necessary. These follow three stages: retrieval, restoration, and retribution.

The first stage, retrieval of the body, is conducted by the shrine priest or linguist. Nana Tete Amo explained that the family of the deceased member must provide two bottles of schnapps or gin for retrieval rituals and a white ram for restoration rituals (personal communication, June 22, 2016). The shrine priest or linguist will pour the alcohol as libations at the river site where the drowning occurred. While doing this, they will call the specific river deity's name, ask for forgiveness, and request for the body to come out of the river. Nana Samanhyia Darko II noted that if a person goes into the river once pacification rituals have happened but before the drowned body has come out, it is believed that this person will die within twenty to thirty minutes (personal communication, May 11, 2016). In this way, the water environment is the domain of deities, with human attempts to override this control seen as unstable and dangerous.

The second stage is to restore human respect of the deity and to reestablish an already determined order. ${ }^{4}$ When the body has been retrieved from the river, the ram and schnapps or gin will be taken to the chief's palace

\footnotetext{
${ }^{4}$ See McCaskie for how Asante shrine priests conducted rituals to return to an ordered past rather than a revolutionary future and, by doing so, were "restating the fundamentals of the relationship between Asante society and the abosom [gods/deities]. They castigated the present as error and deviation, but cast the future as a return to the past" (1995, p. 124).
} 
of the jurisdiction - of both land and water - where the victim drowned. The chief then uses these items for purification customs, appealing to the gods and the ancestors to separate himself and other traditional authorities on behalf of Akwamu society from this watery death and to ensure that something like the stofo drowning does not happen again (Nana Tete Amo, personal communication, June 22,2016$).{ }^{5}$ Such rituals seek to restore human-environment relations by acknowledging the latter's superior power.

The third stage is to seek retribution for the drowning. Sometimes a drowning might be interpreted as the result of human violence or caused by evil spirits/witchcraft acting on the request of a human. For such an inauspicious death, once the pacification ceremony is completed and the corpse comes out, the shrine priest or linguist will ask the gods to identify the person who killed the drowned victim. Kwadwo Nyarko, an opinion leader in the community of Dwenease, explained that if the appropriate customs are done, it is believed the gods will spiritually attack the perpetrator who has been the cause of the death, and that this person will confess with their own mouth (personal communication, June 28, 2016). As noted by van der Geest (1980, p. 168) for the town of Kwahu-Tafo in Ghana, and Fontein (2015, p. 50) in relation to Lake Mutirikwi in Zimbabwe, bad or unnatural deaths can also offer opportunity for witchcraft or other accusations based on already-simmering social tensions. ${ }^{6}$

There are also strict distinctions between the life of the community through which the drowned person socially existed and their unnatural death by drowning. In contrast to Akan customary efforts for a "lineage to bury their naturally deceased relatives in a fitting way" (Adinkrah, 2016, p. 153, emphasis in original), a victim of an stวfo death will not be laid in state in the family home and they will not be given a funeral (Nana Afrakoma II, personal communication, September 15, 2017).

Instead, the bodies of the drowned are "consigned to the midden, the place of the dirty and broken" which was historically separated in the cemetery from the area "reserved for their lineage" (McLeod, 1981, p. 38, see also p. 36). Such a person might simply be buried in the ground by the river where the body was retrieved (Okyeame Ampadu, senior Akwamu linguist, personal communication May 6, 2017; Nana Appiah-Nti III, personal communication, June 18,2016). Otherwise, the corpse is taken from the river

\footnotetext{
${ }^{5}$ See also Adinkrah (2016, p. 156) for a similar account of cleansing rituals after a suicide. ${ }^{6}$ Van der Geest (1980, p. 168) argues that spiritual/witchcraft accusations also occur in cases of a natural death, for purposes of resisting the idea of death in general, and to address social grievances. For instance, witchcraft may be suspected for a "good" death as a result of long-life when other relatives die early (Van der Geest, 2004, p. 907).
} 
via the outskirts of the town to the cemetery located just beyond the threshold of social life and community (Okyeame Ampadu, personal communication, May 6, 2017).

These practices reflect the Akan proverb that "se wo wu atofowuo a, yesie wo atsfosie (if you die an unnatural death, you are given an unnatural burial)" (Adinkrah, 2016, p. 153), and Bartle suggests "the more shameful the circumstances of death, the less elaborated and ostentatious are the funeral rites" (1977, p. 392; but see disagreement by van der Geest (2004, p. 905)). Nana Appiah-Nti III reasoned that if a funeral is conducted for an unnatural death, this accident will occur to someone else in the society. Adinkrah similarly writes, "Akans believe that if such deaths were granted elaborate ritual observances, more of such deaths would occur in the future" $(2016, \mathrm{p}$. 151). Not to be given a fitting funeral in death is to suffer "the ultimate disgrace" (van der Geest, 2004, p. 901; see also Gilbert 1988, p. 297 for the Akuapem). ${ }^{7}$

By shortening or circumventing funerary and burial practices for stวfo deaths, community members seek to protect the centre - the home/village/and land based understandings of order - from the unnatural and difficult to understand space of drowning as embodied in the corpse. This protection of the centre is also reflected in the customary rule that a chief should not see the corpse of an unnatural death. Ellis (1966 [1890], p. 160) notes the requirement of purification post-contact with a corpse among the Ewe, and Huber (1958, pp. 167-168) outlines purification rituals required in Adangme culture if a person is killed in an accident. In a similar manner, if an Akwamu chief does see a dead body, he must be purified.

During fieldwork, I observed and participated in four such purification rituals where Akwamu chiefs, as well as queen mothers and linguists, were cleansed by a combination of water mixed with schnapps or gin poured as libations and the blood of a sacrificed ram. Through this process, the chief and traditional authorities - on behalf of broader society - are believed to transition from death back into a state of social life where they can return to everyday domestic activities such as eating and resting in their residence. What is key for this article is the space in which this purification ritual occurs. A drowned victim is spatially constrained to the river banks and the cemetery - the peripheries of land-based hierarchy of humans with their deities in ordered social life. In contrast, although also using water, a purification ritual

\footnotetext{
${ }^{7}$ Van der Geest observed that the indignity continues as those who died unnaturally, or tragically, will not have their name articulated during alcoholic libations to remember the family dead: "to be mentioned or not ... during libation is indeed one of the most 'objective' indications of good and bad death" (2004, p. 905).
} 
for a chief occurs in their palace compound - within the village land considered central to Akwamu traditional authority.

To illustrate some of the understandings above, while on fieldwork I heard that a boy had drowned and his community had brought the drowning victim's body into the village to hold a funeral, a cultural taboo. Nana Appiah-Nti III described this as a violation of customary law and said that the fine was seven sheep and seven schnapps as well as some money as required for pacification and purification rituals (personal communication, June 18, 2016). He said that the people who violated this taboo in this case were Ewe, not Akwamu, reflecting inter-ethnic tensions as depicted through hydro-sociality. The case was referred to the Akwamu chief in charge of the jurisdiction to resolve the matter. While I later learnt that there had been a misunderstanding and the corpse was not in fact brought into the village, the seriousness with which these taboos continue to be taken, the hierarchy of who oversees such cases and the economic as well as social costs that the flouting of such taboos can bring is significant.

\section{Undercurrents of power: Interpretation}

Van der Geest notes that "concepts of 'good' and 'bad death' ... are not fixed and unchangeable categories ... the definitions allow some room for manoeuvring" (van der Geest, 2004, p. 908). Akwamu traditional authorities interpret a bad or unnatural death by drowning to reflect breakdowns in human-environment and/or inter-human relationships. Such interpretation, however, does not happen in a vacuum. Rather, interpretations of drowning as a non-human, spiritual and environmental judgement of the moral character of other humans is a form of manoeuvring that both reflects and helps constitute social and economic power relations in Akwamu society. (Male) shrine priests, (usually male) linguists, and other traditional leaders possess the authority to interpret drownings. They also have authority to impose sanctions on those who violate mortuary customs and taboos designed to limit the chance of spiritual retribution.

Two factors ensure that interpretations of drowning victims as immoral are unlikely to be challenged. First, the drowned victim has no opportunity for rebuttal of the interpretation since they are physically dead. While there is a belief in spiritual life after physical death, the omitted or truncated mortuary and funeral rites discredit the deceased person's legacy and any spiritual influence over family since not all spirits are considered suitable to become ancestors (van der Geest 1980, pp. 161-162). Therefore, the judgement and assumed justice believed to be delivered by the gods via river drownings, as interpreted by humans, seems to go unchallenged by the 
accused and now-deceased victim themselves. Bleek observed a similar pattern of accusing already deceased people of immoral activities, noting a high proportion of those accused of witchcraft (victim or perpetrator) being deceased family members (1976, p. 528). Second, there is a cultural fear of future repetition of such an unnatural drowning, as well as the blame for a repeat of such an event. This discourages the drowning victim's family and the broader community from questioning the interpretation.

For the Asante, Marleen de Witte (2003) noted an economic relationship to natural deaths, as realised in the space of funerals and beyond. For the Akwamu, unnatural deaths can also bring economic costs to the deceased's family in funding the materials for pacification and purification rituals as outlined above (Nana Afrakoma II, personal communication, September 15, 2017). At times, the same people that interpret the drowning as evidence of deities inflicting justice via the environment may materially benefit from this interpretation through the ram, schnapps/gin and, sometimes, monetary fines provided as part of follow-up rituals of retrieval, restoration and perhaps also retribution.

Adinkrah wrote of a case of aggravated youths in Atimpoku, a community within the Akwamu traditional area, who stormed the local chief's palace and accused traditional authorities of taking fines from families who had experienced a relative's unnatural death (2016, pp. 158-159). They also reported requests (with financial incentive) made to chiefs and elders to ask pardon from the ancestors and other spirits to hold a funeral for bad deaths that inevitably came in contravention of the dictates of tradition (Adinkrah, 2016, pp. 158-159). This suggests a level of negotiability even in seemingly rigid customs. It seems that the power of interpretation of unnatural deaths, such as that of drowning, can provide an opportunity for social and economic gain by some humans over other humans. Water as disorder and death operates to reinforce social order and life on land.

\section{Conclusion}

In this article, I have explored how river water - valued for its life-giving qualities - is interpreted when it becomes the opposite: the cause of death by drowning. Akwamu classify drowning as a bad or unnatural death and further categorise it as either accidental or spiritually invoked, the latter of which is interpreted as a non-human spiritual valuation of human morality.

The interpretation of an unnatural death in water highlights a breakdown in social relationships - both human-environment and inter-human - with drownings framed as the environment enacting justice. Such breakdowns are mitigated and restored through pacification and purification rituals. These 
involve the retrieval of the body, recognition of water deities as the higher authority of humans to restore order and, on occasion, also retribution by appeasing the river deity to draw out a confession from the killer of the drowned victim, and to judge and punish appropriately. Moreover, taboos strongly demarcate the widely-understood, grounded, everyday state of Akwamu society from the character of an unnatural, watery death. Drowned victims are denied burial and funeral rites of 'naturally' deceased members of society and are also disqualified from becoming desired ancestral spirits (Adinkrah, 2016, pp. 143-144).

Akwamu authorities such as chiefs and shrine priests have described river water, governed by related deities, as a fair and unbiased avenue through which to resolve human disputes. In this understanding, drownings are thought to reflect transparently the true moral worth of the drowned victim. The Akwamu people see their water environment as, rather than in need of, justice. But stir the waters and you will find that interpretations of drownings may serve some human interests over others and work to reinforce social hierarchy. Because dead victims cannot talk back and families fear blame for repeated misfortunes, contestations to social (re-)order are pre-emptively silenced. It appears Akwamu reflections on rivers as justice may carry a powerful undercurrent.

\section{Acknowledgements}

I would like to thank all the Akwamu research participants as cited in this article and also those who informally shared information. My thanks as well to the adjudicators of the Cherry Gertzel/African Studies Association of Australasia and the Pacific (AFSAAP) 2017 Postgraduate Prize, Associate Professor Geoffrey Hawker as editor, and Dr Tass Holmes as peer reviewer, Associate Professor Matt Tomlinson, Dr Benedikt Pontzen, Matthew Gmalifo Mabefam and Dr Emmanuel Lohkoko Awoh for their generous readings and recommendations to develop this article. Thank you also to Professor Sjaak van der Geest for a conversation in which he offered valuable advice. Any errors contained in this article are my own.

\section{Funding}

This research was made possible due to an Australian Government Research Training Program (RTP) Scholarship. I am also grateful to AFSAAP for their financial contribution, received as part of the Cherry Gertzel/AFSAAP 2017 Postgraduate Prize. 


\section{References}

Adinkrah, M. (2016). Suicide and mortuary belief and practices of the Akan of Ghana. OMEGA: Journal of Death and Dying, 74(2), 138-164.

Agyekum, A. B. (2015). A short history of Akwamu. Atimpoku, Ghana: Selfpublished (obtained from the author).

Akyeampong, E. K. (2001). Between the sea and the lagoon: An eco-social history of the Anlo of Southeastern Ghana, c.1850 to recent times. Oxford: James Currey.

Amuquandoh, F. (2010). Lay concepts of tourism in Bosomtwe Basin, Ghana. Annals of Tourism Research, 37(1), 34-51.

Anand, N. (2011). PRESSURE: The PoliTechnics of water supply in Mumbai. Cultural Anthropology, 26(4), 542-64.

Apoh, W., Wissing, K., Treasure, W., and Fardin, J. (2017). Law, land and what lies beneath: Exploring mining impacts on customary law and cultural heritage in Ghana and Western Australia. African Identities, 15(4), 367-386.

Austin-Broos, D. (2009). Arrernte present, Arrernte past: Invasion, violence, and imagination of Indigenous Central Australia. Chicago: University of Chicago Press.

Baaré, A. (1986). 'Omgaan met de dood: Emoties en dodenrituelen bij de Akan in Ghana (Coping with death: Emotions and death rituals among the Akan in Ghana)'. Master's thesis, University of Amsterdam.

Bartle, P. (1977). 'Urban migration and rural identity: An ethnography of a Kwawu community'. Doctoral dissertation, University of Ghana, Accra.

Beecham, J. (1968 [1841]). Ashantee and the Gold Coast: Being a sketch of the history, social state and superstitions of the inhabitants of these countries with a notice of the state and prospects of Christianity among them. London: Dawsons.

Bichsel, C. (2016). Water and the (infra-)structure of political rule: A synthesis. Water Alternatives, 9(2), 356-72.

Bleek, W. (1976). Witchcraft, gossip and death: A social drama. Man, 12, 526-541.

Cless, K. (2012). People at the well: Experiences around water. In H. P. Hahn, K. Cless and J. Soentgen (Eds.), People at the well: Kinds, usages and meanings of water in a global perspective (pp. 98-125). Frankfurt: Campus Verlag.

Cless, K. and Hahn, H. P. (2012). Introduction. In H. P. Hahn, K. Cless and J. Soentgen (Eds.), People at the well: Kinds, usages and meanings of water in a global perspective (pp. 9-22). Frankfurt: Campus Verlag. 
Crutzen, P. and Stoermer, E. (2000). The Anthropocene. IGBP Newsletter Royal Swedish Academy, 41, 17-18.

de Witte, M. (2003). Money and death: Funeral business in Asante, Ghana. Africa, 73(4), 531-559.

Drewal, H. J. (2008). Mami Wata: Arts for water spirits in Africa and its diasporas. African Arts, 41(2), 60-83.

Ellis, A. B. (1966 [1890]). The Ewe-speaking peoples of the Slave Coast of West Africa: Their religion, manners, customs, laws, languages, etc. Oosterhout: Anthropological Publications.

Fontein, J. (2015). Remaking Mutirikwi: Landscape, water and belonging in southern Zimbabwe. Woodbridge, Suffolk: James Currey.

Fortes, M. (1959). Oedipus and Job in West African religion. Cambridge: Cambridge University Press.

Greene, S. (2002). Sacred sites and the colonial encounter: A history of meaning and memory in Ghana. Bloomington: Indiana University Press.

Gilbert, M. (1988). The sudden death of a millionaire: Conversion and consensus in a Ghanaian kingdom. Africa, 58(3), 291-314.

Hahn, H. P. (2012). Water as substance and meaning. In H. P. Hahn, K. Cless and J. Soentgen (Eds.), People at the well: Kinds, usages and meanings of water in a global perspective (pp. 23-43). Frankfurt: Campus Verlag.

Huber, H. (1958). Adangme purification and pacification rituals (West Africa). Anthropos, 53, 161-191.

Krause, F. and Strang, V. (Eds.) (2016). Thinking relationships through water. Society and Natural Resources, 29(6), 633-724.

Linton, J. and Budds, J. (2017). The hydrosocial cycle: Defining and mobilizing a relational-dialectical approach to water. Geoforum, 57, 170-180.

Maru-Lanning, M. (2010). 'Tapuna Awa and the Te Awa Tapunua: An anthropological study of competing discourses and claims of ownership to the Waikato River'. Master's thesis, University of Auckland.

McCaskie, T. (1989). Death and the Asantehene: A historical meditation. Journal of African History, 30(3), 417-444.

McCaskie, T. (1995). State and society in pre-colonial Asante. Cambridge: Cambridge University Press.

McCaskie, T. (2009). 'Water wars' in Kumasi, Ghana. In F. Locatelli and P. Nugent (Eds.), African cities: Competing claims on urban spaces (pp. 135-155). Leiden: Brill. 
McLeod, M. D. (1981). The Asante. London: British Museum.

McWilliam, A., Palmer, L. and Shepherd, C. (2014). Lulik encounters and cultural frictions in East Timor. Australian Journal of Anthropology, 25(3), 304-320.

Menzies, C. R. (Ed.) (2006). Traditional ecological knowledge and natural resource management. Lincoln: University of Nebraska Press.

Miescher, S. (1997). 'Becoming a man in Kwawu: Gender, law, personhood and the construction of masculinities in colonial Ghana, 1875-1957'. Doctoral dissertation, Northwestern University.

Mumma, A. (2005). The link between traditional and formal legal systems. In W. Ndoro and G. Pwiti (Eds.), Legal frameworks for the protection of immovable cultural property in Africa (pp. 22-24). Rome: ICCROM.

Nketia, J. H. (1955). Funeral dirges of the Akan people. London: Achimota. Nketia, J. H. (1969 [1955]). Funeral dirges of the Akan people. New York: Negro Universities Press.

Opoku, K. A. and Wicker, K. O. (2008). Abidjan Mamiwata and Aba Yaba: Two profiles of Mami/Maame Water priesthood in Ghana. In H. J. Drewal (Ed.), Sacred waters: Arts for Mami Wata and other divinities in Africa and the diaspora (pp. 171-190). Bloomington: Indiana University Press.

Peters, P. (1994). Dividing the commons: Politics, policy, and culture in Botswana. Charlottesville: University Press of Virginia.

Rattray, R. S. (1923). Ashanti. Oxford: Clarendon Press.

Rattray, R. S. (1927). Religion and art in Ashanti. London: Oxford University Press.

Rockefeller, S. (2011). Flow. Current Anthropology, 52(4), 557-578.

Roy, E. A. (2017, March 16). New Zealand river granted same legal rights as human. The Guardian. https://www. theguardian.com/world/2017/mar/16/new-zealand-river-grantedsame-legal-rights-as-human-being

Sarpong, P. (1974). Ghana in retrospect: Some aspects of Ghanaian culture. Accra/Tema: Ghana Publishing Corporation.

Schoffeleers, J. M. (1979). Introduction. In J. M. Schoffeleers (Ed.), Guardians of the land: Essays on Central African territorial cults (pp. 1-46). Gwelo: Mambo Press.

Strang, V. (2004). The meaning of water. Oxford: Berg.

Strang, V. (2005a). Knowing me, knowing you: Aboriginal and EuroAustralian concepts of nature as self and other. Worldviews: Global Religions, Culture and Ecology, 9(1), 25-56. 
Strang, V. (2005b). Common senses: Water, sensory experience and the generation of meaning. Journal of Material Culture, 10(1), 92-120.

Talbot-Jones, J. (2017). 'The institutional economics of granting a river legal standing'. Doctoral dissertation, Australian National University, Canberra.

Ubink, J. (2008). In the land of the chiefs: Customary law, land conflicts, and the role of the state in peri-urban Ghana. Leiden: Leiden University Press.

Van der Geest, S. (1980). The image of death in Akan highlife songs. Research in African Literatures, 11(2), 145-174.

Van der Geest, S. (2004). Dying peacefully: Considering good death and bad death in Kwahu-Tafo, Ghana. Social Science and Medicine, 58, 899911.

Watts, L. (2008). 'A political ecology of Warlpiri water rights: A denial of access and land alienation to perennial water sources on leased lands in the Western Desert.' Doctoral dissertation, University of Melbourne.

Wilks, I. (2001). Akwamu 1640-1750: A study in the rise and fall of a West African empire. Trondheim: Department of History, Norwegian University of Science and Technology.

Wittfogel, K. (1957). Oriental despotism: A comparative study of total power. New Haven: Yale University Press. 